\title{
Patterns in vertical distribution and their potential effects on transport of larval benthic invertebrates in a shallow embayment
}

\author{
Michelle J. Lloyd ${ }^{1, *}$, Anna Metaxas ${ }^{1}$, Brad deYoung ${ }^{2}$ \\ ${ }^{1}$ Department of Oceanography, Dalhousie University, Halifax, Nova Scotia, Canada B3H 4R2 \\ ${ }^{2}$ Department of Physics and Physical Oceanography, Memorial University, St. John's, Newfoundland, Canada A1B 3X7
}

\begin{abstract}
Measurements of larval vertical distributions at high temporal and spatial resolutions as well as larval behavioural responses to environmental characteristics are needed to parameterize bio-physical models of larval dispersal or transport. We studied larval vertical distribution for 7 taxonomic groups (gastropods, bivalves, polychaetes, bryozoans, asteroids, carideans and brachyurans), with different morphology, swimming abilities and life-history strategies, and examined whether these vary with physical or biological factors and periodic cycles (diel period and tidal state) in the field. Using a pump, we collected plankton samples at 6 depths $(3,6,9,12$, 18 and $24 \mathrm{~m}$ ), over a 36 and a $26 \mathrm{~h}$ period. Temperature, salinity, fluorescence and current velocity were measured concurrently. Larval vertical distribution varied among taxonomic groups, but 4 patterns could be distinguished: (1) larvae exclusively in the mixed layer (asteroids), (2) larvae predominantly below the thermocline, halocline and pycnocline (gastropods, bivalves, polychaetes), (3) larvae associated predominantly with the fluorescence maximum (bryozoans and carideans) and (4) larval distribution varying dielly (gastropods, polychaetes, carideans and brachyurans). Based on flow velocities and depending on distribution, asteroid larvae were likely to be transported farther than those of bryozoans and carideans, while direction and magnitude of transport varied for the other larvae. For most taxonomic groups, behaviour observed in the field agreed with measured laboratory responses to relevant cues. For asteroids and bivalves, simple behavioural parameters can be generated that can be utilized to improve the accuracy of biophysical models.
\end{abstract}

KEY WORDS: Vertical migration · Temperature $\cdot$ Fluorescence $\cdot$ Diel period $\cdot$ Water column structure $\cdot$ Larval behavior $\cdot$ Larval transport $\cdot$ Biophysical model parameters

Resale or republication not permitted without written consent of the publisher

\section{INTRODUCTION}

For marine benthic invertebrates with a meroplanktonic phase, larval dispersal is critical for the establishment and maintenance of adult populations. Meroplanktonic larvae can reside in the water column for hours to months, thus enabling them to both exploit new habitats or recolonize old ones. The degree of larval exchange between populations can regulate their stability and resilience. Thus, quantification of the mechanisms that drive larval transport, retention and supply, as well as realistic measures of distance travelled, direction and frequency of dispersal, are necessary for management and protection of species and their ecosystems.

Meroplanktonic larvae are typically small $(<0.2 \mathrm{~cm})$ and weak swimmers ( 0.1 to $\left.1.5 \mathrm{~cm} \mathrm{~s}^{-1}\right)$ (Young 1995, Metaxas 2001). Consequently, they are considered incapable of sustained horizontal movement against large-scale horizontal currents (velocities $>100 \mathrm{~cm}$ $\mathrm{s}^{-1}$ ). Horizontal dispersal patterns are mainly attributed to advection along dominant directions of flow. 
Horizontal currents can advect larvae of coastal species offshore, leading to failure of recruitment to nearshore habitats (Shanks 1995).

Meroplankton are capable of movement against vertical currents, as their swimming or sinking speeds are greater than weak vertical current velocities $\left(0.1 \mathrm{~cm} \mathrm{~s}^{-1}\right.$ ) (Chia et al. 1984, Metaxas 2001). Larval movement between layers of different velocities can alter the horizontal direction and magnitude of larval transport and dispersal (DiBacco et al. 2001, Metaxas 2001). Through changes in buoyancy or propulsion by ciliary or muscular activity, some crustacean and bivalve larvae can cover large distances vertically, in some cases many times a day (Cronin \& Forward 1986, Manuel et al. 1996, dos Santos et al. 2008). Larval movement can possibly be triggered through an innate behavioural response to physical and/or chemical stimuli. Consequently, sensory detection of the environment can potentially affect larval direction of movement and/or swimming behaviour (acceleration, deceleration, cessation) (Kingsford et al. 2002). Currently, the role of larval behaviour in affecting their horizontal transport remains elusive, and the conditions under which larvae may actively regulate their depth are poorly understood (Metaxas \& Saunders 2009).

The vertical distribution of meroplankton in the water column can be related to physical and biological discontinuities. Many larvae respond to abiotic (e.g. temperature, salinity, density, pressure, gravity, light, flow regimes, tides and waves) and biotic (predators, food and conspecifics) cues that can in turn be related to features in the water column (Young 1995), thus possibly shaping larval vertical distributions. For example, aggregations of bivalve larvae at the chlorophyll maximum (Raby et al. 1994) and the pycnocline (Tremblay \& Sinclair 1990b) have been observed in the field. In the laboratory, larvae (e.g. echinoderms, bivalves and crustaceans) respond to food patches (Metaxas \& Young 1998, Sameoto \& Metaxas 2008b), gradients in temperature (McConnaughey \& Sulkin 1984, Daigle \& Metaxas 2011) and salinity (Mann et al. 1991, Sameoto \& Metaxas 2008a,b), and to the presence of predators (Metaxas \& Burdett-Coutts 2006), and their response to cues can be measured through changes in vertical or horizontal distribution, or swimming speeds. In the field, however, behaviour is typically inferred from changes in spatial and temporal patterns in abundance and distribution on many scales. Since patchy larval distributions can confound these patterns, our understanding of larval behaviour is based mainly on laboratory studies.
Some larval taxa appear to respond to cues linked to predictable cycles, such as tidal states, diel periods, lunar phases or ontogenetic stages. For example, crustacean larvae relate their movement to changes in the tide, and as a result, increase the probability of import or export in or out of bays (Garrison 1999, DiBacco et al. 2001). Some larval gastropods, bivalves, polychaetes, echinoids and crustaceans respond to diel cues either by diel migration (toward the surface at night and deeper waters during the day) or reverse-diel migration (Pennington \& Emlet 1986, Young \& Chia 1987, Poulin et al. 2002). Larval bivalves are thought to respond to lunar cues, which are generally linked to light intensity and/or a combination of tidal and diel cues (Manuel \& O'Dor 1997). Older larvae of bivalves and decapods tend to be more abundant near the seafloor than younger ones, presumably due to an increase in specific gravity and change in morphology or behaviour (Brookins \& Epifanio 1985, Gallager et al. 1996, Tamaki et al. 2010). Near-bottom distribution presumably enhances the probability of locating a suitable site for settlement. Larval movement in response to these periodic cues is suggested as a mechanism to avoid predation, optimize feeding and increase or decrease transport (Young 1995).

Quantifying larval transport in the field is difficult due to small larval size and prolonged planktonic duration (days to months). Consequently, biophysical models are increasingly being used to quantify larval transport and supply to the benthos. The ability of these models to predict larval distributions and transport depends on the accuracy of estimates of the physical and biological parameters in the field, and often these are location-, species- and life history stage-specific (Metaxas \& Saunders 2009). Invertebrate larvae are often modeled as passive (nonswimming) particles, and their dispersal is mainly attributed to physical processes. Often these models cannot account for observed larval distributions (Metaxas \& Saunders 2009), possibly because parameterizations of biological variables are based mainly on laboratory studies, where larval behaviors are often measured on small scales $(\mathrm{cm})$ and in the absence of flow (Metaxas 2001, Kingsford et al. 2002, Metaxas \& Saunders 2009). As more biological parameters (e.g. vertical migration, larval behaviour, growth, mortality and settlement behaviour) are incorporated into these models, the outputs can change significantly (North et al. 2008, Metaxas \& Saunders 2009, Gilbert et al. 2010, Huebert et al. 2011). Thus, to accurately model larval transport, we need better measures of biological parameters in the field. Spa- 
tial and temporal measures (continuous, or at least at high frequency) of changes in larval vertical distribution relative to associated changes in the water column are needed to quantify larval behaviour in situ.

To date, most studies of vertical distribution or migration in the field focus on a single species or taxonomic group. Less than a handful of studies examine changes in vertical distribution concurrently for multiple taxonomic groups (e.g. gastropods, bivalves, crustaceans and polychaetes) with different swimming abilities, morphologies and life histories. In these studies, changes in vertical distribution were measured in an upwelling-downwelling region in the outer Banks of North Carolina (depth: 20-25 m) (Garland et al. 2002) or in an artificial lagoon at sluice dock Ostend (depth: $1.5 \mathrm{~m}$ ) (Daro 1974). Our study extends previous knowledge by examining changes in the larval vertical distribution for different taxonomic groups in a coastal embayment during a stable period (i.e. water column structure remains consistent), at high temporal frequencies (h) and spatial resolutions (m). We examined whether changes in larval vertical distribution in St. George's Bay, Nova Scotia, Canada, within the season of high larval abundance, over a 36 and a $26 \mathrm{~h}$ period, during the full moon and quarter moon, respectively. We examined distributions of 7 different taxonomic groups, with contrasting life histories (i.e. planktonic larval durations, developmental and feeding modes, etc.), morphologies (size and form) and swimming abilities (weak to strong), under the same environmental conditions. This approach allowed us to assess variation among taxa in the factors that may regulate larval vertical distributions in the field. Since behavioural responses to cues (e.g. temperature, salinity, density, food, light etc.) for some of these taxonomic groups (bivalves, asteroids, brachyurans) have been measured in laboratory studies, we can associate changes in their vertical distribution in the field with published behavioural responses observed in the laboratory. Thus, we can begin to quantify the role of larval behaviour in the field, which in turn can improve the parameterization of biological variables for biophysical models, and ultimately improve estimates of transport for different taxonomic groups of larvae.

\section{MATERIALS AND METHODS}

\section{Plankton sampling and processing}

Plankton samples were collected with a cast iron, high volume portable trash pump, in St. George's
Bay, Nova Scotia, Canada $\left(45^{\circ} 46.98^{\prime} \mathrm{N}, 61^{\circ} 46.66^{\prime} \mathrm{W}\right.$; depth $=25-26.5 \mathrm{~m}$; for details of the study site, see Lloyd et al. 2012), during a spring (full moon: 6-7 August 2009) and neap (quarter moon: 1213 August 2009) tide. The discharge from the pump was directed into a submerged $200 \mu \mathrm{m}$ mesh plankton net to prevent damage to the larvae. While plankton sampling, the intake was moved vertically through a depth interval of $\sim 1 \mathrm{~m}$ for $5 \mathrm{~min}$ for a sample volume of $\sim 4.4 \mathrm{~m}^{3}$. Plankton were sampled at 3,6 , $9,12,18$ and $24 \mathrm{~m}$ every $2 \mathrm{~h}(10: 00,12: 00,14: 00$, 16:00, 18:00, 20:00, 22:00, 00:00, 02:00, 04:00, 06:00 and 08:00 h), over a period of $\sim 36$ (6-7 August 2009) or 26 h (12-13 August 2009). Sampling depths were chosen to provide a stratified range of vertical positions above, below and within the pycnocline, where larvae were expected to be found based on the literature, while still sampling the entire water column. The net and codend were washed down with filtered seawater to concentrate larvae for preservation, and plankton samples were preserved in $90 \%$ ethanol. In the laboratory, larvae of benthic invertebrates were sorted and enumerated to major taxonomic groups (gastropods, bivalves, bryozoans, polychaetes, asteroids, brachyurans, carideans). Hereafter, we use these taxonomic names to designate the corresponding larvae. For each taxon at each sampling time, depth and sampling period, larval abundance was calculated and standardized to the number of larvae $\mathrm{m}^{-3}$. For the purpose of statistical analyses, larval abundance for each taxonomic group was normalized using

$$
x^{\prime}{ }_{i j}=\frac{x_{i j}-\mu}{\mathrm{SD}}
$$

where $x^{\prime}=$ normalized larval abundance at depth $i$ at time $j, x=$ larval abundance at depth $i$ at time $j, \mu=$ overall mean larval abundance across all depths and sampling times and both sampling periods and SD = overall standard deviation in larval abundance across all depths and sampling times and both sampling periods. For further details of the plankton sampling and processing, see Lloyd et al. (2012).

\section{Sampling and processing of physical characteristics}

Temperature, salinity, pressure, fluorescence and current velocities (vertical: $w$, north-south: $V$ and east-west: $u$ ) were measured in the water column, averaged to $1 \mathrm{~m}$ depth bins from 1 to 23-25 $\mathrm{m}$ depth, with a conductivity-temperature-depth (CTD) recor- 
der, a fluorometer and an acoustic Doppler current profiler (ADCP) (for details, see Lloyd et al. 2012). Before and during each plankton sampling time, 2 profiler casts were made. Some malfunctioning of the CTD and the fluorometer resulted in incomplete data sets. The ADCP was deployed on the seafloor, sampling over $1 \mathrm{~m}$ depth bins from just above the bottom to just below the surface, every 20 min from 11 July to 22 August 2009. A chain of VEMCO thermistors was attached to the edge of the ADCP mooring, and distributed throughout the water column, every $3 \mathrm{~m}$ from 3 to $24 \mathrm{~m}$ depth. For further details of the sampling of physical characteristics, see Lloyd et al. (2012).

For each profiler cast, only data collected during the down-casts were used, and any outliers in temperature, salinity or fluorescence were identified using a moving average and removed. Temperature measurements were averaged between the 2 casts (before and during plankton sampling), unless the CTD failed to record during one of the casts. Temperature, salinity and fluorescence were averaged into $1 \mathrm{~m}$ depth bins, and density calculated for each depth using the state equation for seawater ('swstate' function for Matlab [The Mathworks Co.] developed by Woods Hole Science Center [2011]) for each sampling time. Vertical temperature, salinity and density gradients for each sampling time were calculated as $\Delta T / \Delta z, \Delta S / \Delta z, \Delta \sigma_{t} / \Delta z$, respectively, where $T$ is temperature $\left({ }^{\circ} \mathrm{C}\right), S$ is salinity, $\sigma_{t}$ is density $(\rho-1000)$ and $z$ is depth $(\mathrm{m})$. For each sampling time, the depths of the thermocline, halocline and pycnocline, in a vertically stratified water column, were identified as the first depth bin where the vertical temperature, salinity and density gradients over $1 \mathrm{~m}$ were $\geq 0.5^{\circ} \mathrm{C} \mathrm{m}^{-1}$, $\geq 0.05 \mathrm{~m}^{-1}$ and $\geq 0.14 \mathrm{~kg} \mathrm{~m}^{-4}$, respectively (since variation in vertical gradient in the mixed layer was minimal). The depth of the fluorescence maximum was where the greatest fluorescence value was recorded. For further details of the profiler data processing, see Lloyd et al. (2012).

For both the ADCP and thermistor data, missing or unreliable data were either replaced by linearly interpolated values from surrounding points if there were sufficient data (typically 1 or 2 points); or were removed entirely, and data from the upper $1 \mathrm{~m}$ of the water column were discarded due to side-lobe contamination of the signal from the surface. The current velocity components and the temperature data were filtered to remove high-frequency variability, for which the energy at periods below $2 \mathrm{~h}$ has been removed. For further details of the ADCP and thermistor data processing, see Lloyd et al. (2012).

\section{Statistical analyses}

Temporal correlation in plankton abundance among sampling times was examined with autocorrelation analyses of the mean depth distribution (MDD) for each taxonomic group and sampling period using Matlab. This allowed us to determine the temporal lag at which autocorrelation is not significant and temporal dependency no longer present (Supplement 1 at www.int-res.com/articles/suppl/ m469p037_supp.pdf). This analysis revealed that the correlation among immediately adjacent ( $2 \mathrm{~h}$ lag) sampling times was not significant $(p>0.05)$ for all combinations of taxonomic groups, except for gastropods, bivalves and polychaetes during the full moon. For these 3 taxonomic groups, temporal dependency was absent by Lag 2 (i.e. 4 h, every second sampling period). Based on these results, we concluded that sample autocorrelation was minimal when the entire suite of sampling periods was considered, and treated sampling times as independent from one another.

The relationships between depth-specific normalized temperature (negatively correlated with depth, salinity and density [Supplement 2 at www.intres.com/articles/suppl/m469p037_supp.pdf]), fluorescence, $w, v$ and $u$ and depth-specific normalized larval abundance were examined with multiple backwards-elimination regressions. Only significant relationships between environmental variables (excluding salinity, density and depth due to multicollinearity) and larval abundance as determined with simple linear regressions (Supplement 3 at www. int-res.com/articles/suppl/m469p037_supp.pdf) were included in the multiple regressions. Because the normalized larval abundance data failed to meet the assumptions of normality and heterogeneity for linear regressions, as determined by examining the residuals, they were $\log (x+2)$ transformed. We examined temporal changes in the vertical distributions of larvae using analysis of variance (ANOVA), as manifested by the interaction terms between depth and either diel period or tidal state. Depending on sampling time, abundance data from both sampling periods were assigned to 2 diel (day and night) and 4 tidal categories (ebb, flood, high and low). Based on sunset and sunrise times published by Environment Canada, we identified 18 day (8:00, 10:00, 12:00, 14:00, 16:00 and 18:00 h) and 6 night (22:00, 00:00 and 02:00 h) sampling times for both sampling periods combined. Dawn (4:00 and 6:00 h) and dusk $(20: 00 \mathrm{~h})$ categories were excluded to minimize uncertainty in light levels. Based on tidal 
height, there were 10 ebb tide (decreasing tidal height), 9 flood tide (increasing tidal height), 6 high tide and 6 low tide tidal state sampling times for both sampling periods combined. Because there were not enough replicates to test all 3 factors (depth, tidal state and diel period) simultaneously, two 2-way ANOVAs were performed followed by Tukey's honestly significant difference (HSD) post-hoc tests to test the effects on normalized larval abundance of: (1) diel period and depth and (2) tidal state and depth. Given the large number of possible comparisons and statistical tests, we used $\alpha$-values of 0.01 for linear regressions and ANOVAs and of 0.05 for Tukey's HSD. Although a more conservative $\alpha$-value was used, the Bonferonni adjustment was considered too conservative $(\alpha$-value $=0.007$ ), greatly increasing the probability of Type II error, compared to other adjustment statistics. All correlations, linear regressions, ANOVA and Tukey's HSD statistical analyses were conducted with SPSS 17.0.

\section{Transport estimates}

Estimates of larval transport over short temporal scales were calculated from progressive vector plots, where the distance travelled was calculated at 20 min intervals for a $24 \mathrm{~h}$ period, at 3, 6, 9, 12, 18 and $23 \mathrm{~m}$ depth, using 3 start times $(10: 00,16: 00$ and 22:00 h) and over both sampling periods. For larvae maintaining a constant depth over the entire $24 \mathrm{~h}$ (i.e. $3,6,9,12,18$ or $23 \mathrm{~m}$ ), transport (distance and direction) was calculated as the vector between the start and end position at a single depth. For larvae with diel periodicity in vertical distribution, transport was calculated as the sum of either 2 or 3 vectors, each describing transport during the night and day (e.g. between 22:00 and 06:00 $\mathrm{h}$, and between 06:00 and 22:00 h); or during the day, night and day (e.g. between 10:00 and 22:00 h, 22:00 and 06:00 h, and 06:00 and 10:00 $h_{\text {; }}$ or between 16:00 and 22:00 $h$, 22:00 and 06:00 $\mathrm{h}$, and 06:00 and 16:00 h), respectively. To calculate these separate vectors, we used: (1) current velocities at 3 or $12 \mathrm{~m}$ for the first period, and currents at 18 or $23 \mathrm{~m}$ for the second period; or (2) currents at 18 or $23 \mathrm{~m}$ for the first and third period, and currents at 3 or $12 \mathrm{~m}$ for the second period. For these larvae, we have assumed migration from a daytime depth (either 18 or $24 \mathrm{~m}$ ) to a shallower (either 3 or $12 \mathrm{~m}$ ) night-time depth. Although progressive vector diagrams, calculated from a single point, are a useful method to estimate and examine general patterns in larval transport; this method has weak- nesses, particularly when applied over longer time periods (Gawarkiewicz et al. 2007).

\section{RESULTS}

\section{Physical structure of the water column}

The structure of the water column remained relatively consistent at the sampling station across both sampling periods (Lloyd et al. 2012). There was a strong vertical gradient in temperature ranging from $\sim 22^{\circ} \mathrm{C}$ at the surface to $\sim 4^{\circ} \mathrm{C}$ at $25 \mathrm{~m}$, (mean $\pm \mathrm{SD}$ : $17 \pm 4^{\circ} \mathrm{C}$ ). Salinity ranged from $\sim 29$ at the surface to $\sim 31$ at $25 \mathrm{~m}$ (mean \pm SD: $29.4 \pm 0.4$ ), and density ranged from $\sim 21 \mathrm{~kg} \mathrm{~m}^{-3}$ at the surface to $\sim 24 \mathrm{~kg} \mathrm{~m}^{-3}$ at $25 \mathrm{~m}$ (mean $\pm \mathrm{SD}: 21.3 \pm 1.3 \mathrm{~kg} \mathrm{~m}^{-3}$ ) (Fig. 1). The water column was strongly stratified, with the thermocline, halocline and pycnocline located on average at $\sim 12-15 \mathrm{~m}$ (depth range: 10-18 m) (Fig. 1). Temperature was strongly negatively correlated with depth, salinity and density (Supplement 2), and the clines of all parameters overlapped (Fig. 1). Water column structure was primarily a function of changes in temperature, since the average differences among profiles in temperature, salinity and density were $12^{\circ} \mathrm{C}, 1.1$ and $3.0 \mathrm{~kg} \mathrm{~m}^{-3}$, respectively, and stratification in St. George's Bay is associated with summer warming. Due to instrument failure or malfunction, there were many missing data for each environmental variable measured, particularly for salinity (salinity: $35 \%$ versus temperature: 10\%) (Lloyd et al. 2012). Salinity measurements within and among profiles were abnormally noisy, and considered suspect. Consequently, we only present patterns in larval abundance with temperature and the thermocline, although salinity (density) and the halocline (pycnocline), respectively, may be responsible for the same patterns. Fluorescence ranged between 0.09 and 0.35, peaked at depths between 13 and 18 m (Fig. 1), but did not vary between day and night (Lloyd et al. 2012). In our study, fluorescence was used as a proxy for food (i.e. phytoplankton), although it may not represent all phytoplankton communities (e.g. eukaryotic phytoplankton, aggregates) (Prairie et al. 2010).

Overall, no strong, persistent circulation patterns were detected in summer 2009. Mean currents within St. George's Bay were variable and tended to be depth-dependent (Lesperance et al. 2011). This pattern is consistent with an earlier study in St. George's Bay (Petrie \& Drinkwater 1978). While Petrie \& Drinkwater (1978) described a clock-wise circulation, both at the surface and near the bottom, 


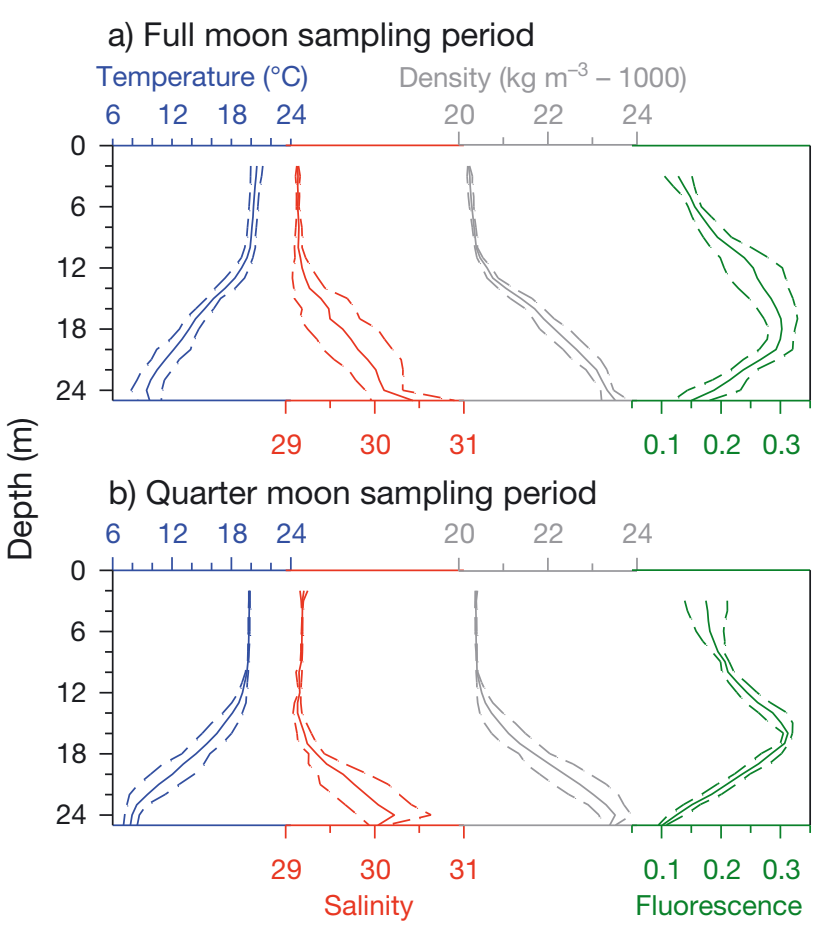

Fig. 1. Gradients in temperature, salinity, density and fluorescence in the water column at St. George's Bay, Nova Scotia, calculated from profiler casts (mean [solid] \pm SD [dashed] over each sampling period) during (a) full moon (6-7 August 2009) and (b) quarter moon (12-13 August 2009) sampling periods. Fluorescence is measured in relative units

their and our data show substantial temporal and spatial variability in the current field. The tides provide regular forcing of the bay, but wind forcing leads to quite variable circulation, typical of such a semi-enclosed coastal embayment. During our sampling periods, the horizontal current velocities were relatively weak $\left(<15.0 \mathrm{~cm} \mathrm{~s}^{-1}\right.$, measurement error $<1 \mathrm{~cm} \mathrm{~s}^{-1}$ ), but were stronger during the full moon than the quarter moon (Lloyd et al. 2012). Consequently, shear was greater between depths during the full moon than the quarter moon. Horizontal velocities changed direction during shifts in tidal state, and the shift lag shows significant vertical structure. The vertical velocities were very weak $\left(<0.2 \mathrm{~cm} \mathrm{~s}^{-1}\right.$, measurement error $\left.\pm 0.2 \mathrm{~cm} \mathrm{~s}^{-1}\right)$ and variable, and patterns were likely due to noise (Lloyd et al. 2012).

\section{General trends in the abundance, composition and ontogenetic stages of different taxonomic groups}

We identified larvae of 7 numerically dominant taxonomic groups, with different life histories and swimming abilities: gastropods, bivalves, polychaetes, bryozoans, asteroids, carideans and brachyurans. Bivalve larvae were the most abundant, comprising $59 \%$ of total numerical abundance. The next 2 numerically dominant taxonomic groups were gastropods and bryozoans $(10-30 \%)$, while the remaining groups accounted for $<3.5 \%$ of total abundance. The mean (depth-averaged) abundance of each taxonomic group varied little across time within each sampling period (Fig. 2). Consequently, we assumed that we sampled the same larval population over time, since neither mean (depth-averaged) nor total abundance (M. Lloyd unpubl. data) of each taxonomic group changed over time within each sampling period. The mean (depth-averaged) abundance of most groups also varied little between sampling periods, except for polychaetes, which decreased between 6-7 and 12-13 August 2009 (Fig. 2).

Gastropods were the most diverse taxonomic group, comprising 10 taxa, with Margarites spp. the most abundant ( $\sim 3 \%$ of total gastropods; Fig. 2). Bivalves were composed of at least 2 taxa (possibly more), but only Anomia simplex (30\% of total bivalves at the full moon and $49 \%$ at the quarter moon) could be reliably identified (Fig. 2). Polychaetes comprised at least 4 families, and bryozoans 2 species, with Electra pilosa the most abundant (Fig. 2). Brachyurans included at least 4 taxa, with Cancer irroratus the most abundant (91\%) (Fig. 2). Asteroids and carideans could only be reliably identified to class and infraorder, respectively.

Different ontogenetic stages were present throughout the water column over both sampling periods. Both early and late larval stages, as well as early juveniles, were observed for polychaetes, brachyurans and carideans, whereas only later stages were observed for asteroids. Also, some meroplankton that lack clear ontogenetic features varied in size. For example, gastropods ranged in size from 200 to $900 \mu \mathrm{m}$, and bivalves from 200 to $400 \mu \mathrm{m}$. Ontogenetic stages $<200 \mu \mathrm{m}$ were excluded from this study by the mesh size of the plankton net.

\section{Spatial and temporal patterns in vertical distribution}

Gastropod larvae were found throughout the water column, but abundance was greatest below the thermocline (Fig. 3a). Variation in their abundance was explained mostly by a negative relationship with temperature (Fig. 3a, Table 1). Fluorescence, $w, v$ and $u$ did not explain any of the variation in their 

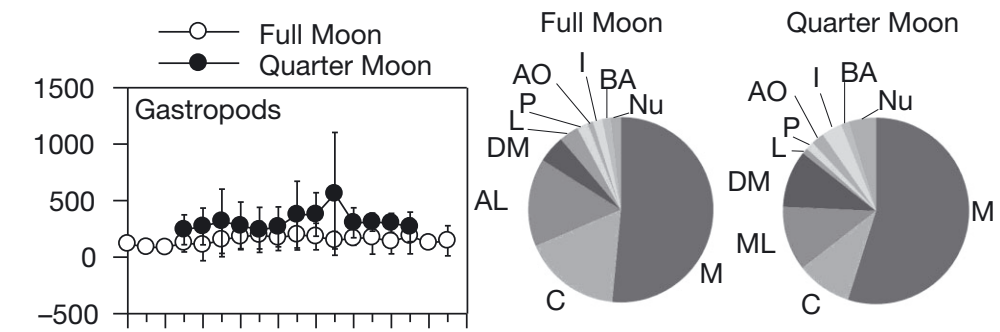

\author{
$\mathrm{M}=$ Margarites spp. \\ $\mathrm{C}=$ Crepidula spp. \\ $\mathrm{AL}=$ Astyris lunata \\ DM = Diaphana minuta \\ $\mathrm{L}=$ Littorina littorea \\ $\mathrm{P}=$ Polinices heros \\ $\mathrm{AO}=$ Arrhoges occidentalis \\ I = llyanassa spp. \\ $\mathrm{BA}=$ Bittiolum alternatum \\ $\mathrm{Nu}=$ Nudibranchia
}
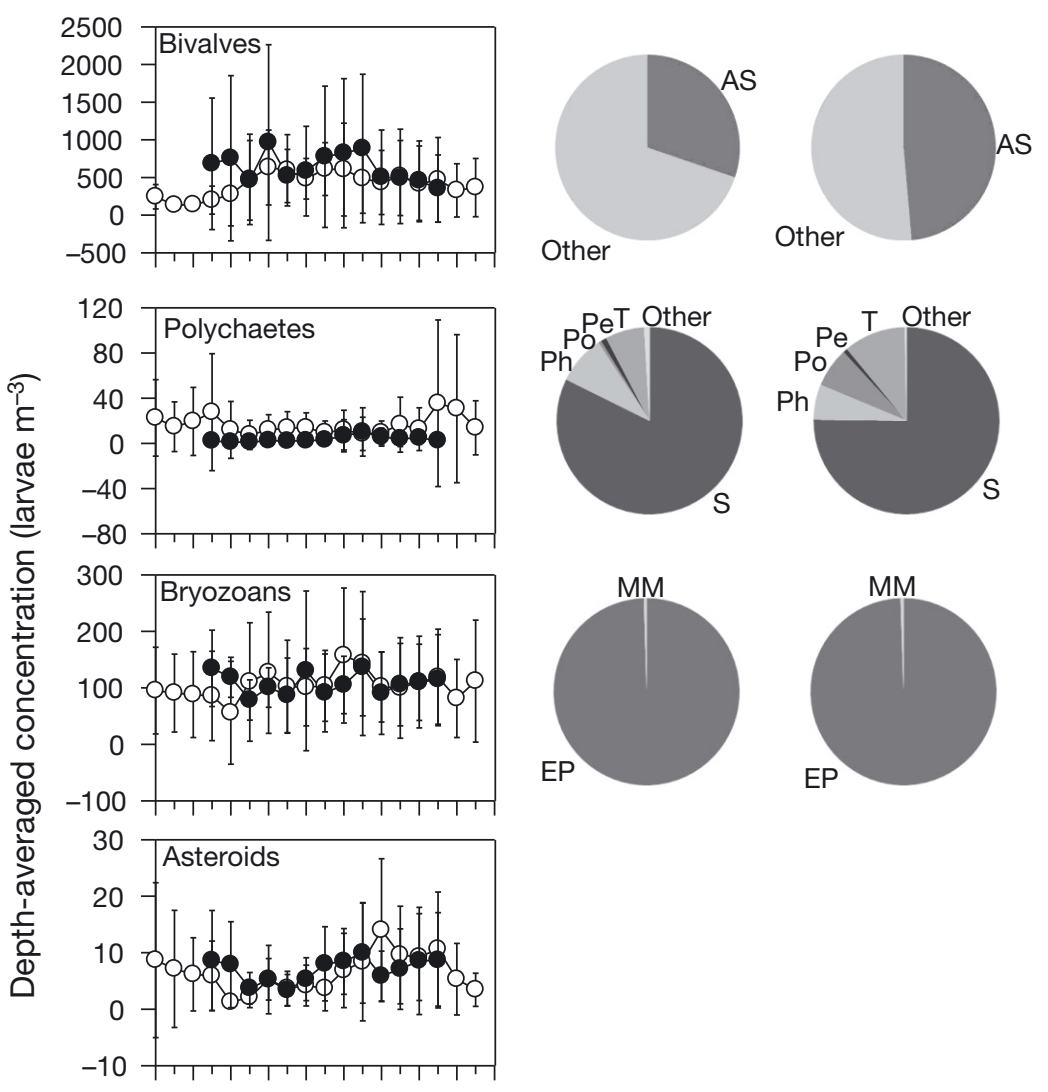

AS $=$ Anomia simplex

Other $=$ unidentified bivalves
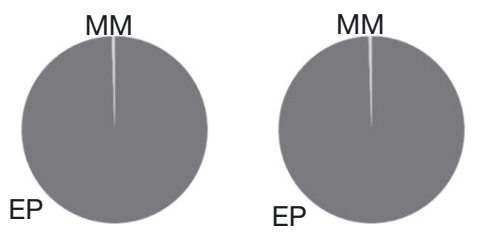

$$
\begin{aligned}
& \mathrm{S}=\text { Spionidae } \\
& \mathrm{Ph}=\text { Phyllocidae } \\
& \mathrm{Po}=\text { Polynoidae } \\
& \mathrm{Pe}=\text { Pectinariidae } \\
& \mathrm{T}=\text { Trochophore } \\
& \text { Other }=\text { unidentified } \\
& \text { polychaetes }
\end{aligned}
$$
$\mathrm{EP}=$ Electra pilosa
$\mathrm{MM}=$ Membranipora membranacea
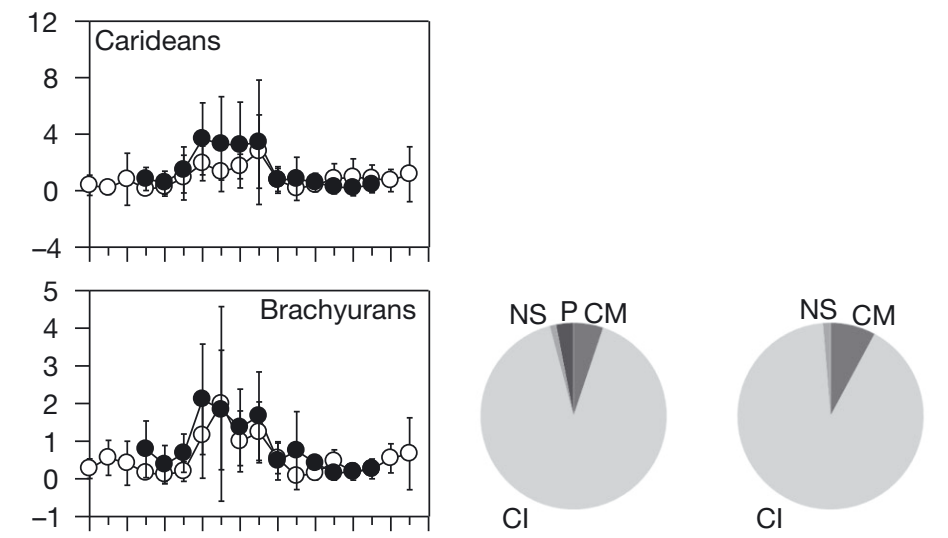
$\mathrm{CM}=$ Carcinus maenas
$\mathrm{Cl}=$ Cancer irroratus
NS = Neopanopeus sayi
$\mathrm{P}=$ Pagurus spp.

৪ ৪ ৪ ৪ ৪ ৪ ৪ ৪

음

Time (hh:mm)

Fig. 2. Depth-averaged concentrations (mean $\pm \mathrm{SD}, \mathrm{n}=6$ ) of larvae of 7 taxonomic groups in St. George's Bay, Nova Scotia, Canada, over a 36 and a 26 h sampling period, during a spring (full moon: 6-7 August 2009) and neap (quarter moon: 12-13 August 2009) tide, respectively. Pie charts: proportional abundance of species or taxon within a taxonomic group, where discrimination was possible 
abundance (Table 1, Supplement 3). Gastropods also exhibited diel vertical migration (Fig. 4). The highest abundance was found at $\sim 24 \mathrm{~m}$ during the day and at $\sim 12 \mathrm{~m}$ at night (Fig. 4, Table 2).

Like gastropods, bivalves occurred throughout the water column, with the greatest concentration below the thermocline (Fig. 3b, Tables 2 \& 3). Most of the variation in their abundance was explained by the thermal structure of the water column (Fig. 3b, Table 1). Similar to gastropods, fluorescence, $w, v$ and $u$ did not explain any of the variation in bivalve abundance (Table 1, Supplement 3). Unlike gastropods, the abundance of bivalves did not vary temporally on either a diel or tidal cycle (Fig. 4, Table 2).

Polychaetes stayed almost exclusively below the thermocline (Fig. 3c, Tables $2 \& 3$ ) and most of the variance in their abundance was explained by a negative relationship with temperature (Fig. 3c, Table 1); fluorescence, $w, V$ and $u$ did not explain any of the variation (Table 1, Supplement 3). This group was found at deeper depths (18-24 m) during the day than at night (Fig. 4, Table 2).

Bryozoans were concentrated at $\sim 18 \mathrm{~m}$, where fluorescence was highest, and most of the variation in their abundance was explained by a positive relationship with fluorescence (Fig. 3d, Table 1), whereas temperature, $w, v$ and $u$ did not explain any variation (Table 1, Supplement 3). Bryozoan abundance did not vary temporally on either a tidal or diel cycle (Tables 2 \& 3).

Asteroids were found almost exclusively in the mixed layer, and much of the variation in their abundance was explained by temperature; there was also a positive relationship with $v$ (Fig. 3e, Table 1) but none with fluorescence, $w$ or $u$ (Table 1, Supplement 3). Like bryozoans, asteroid abundance did not vary temporally on either a tidal or diel cycle (Tables $2 \& 3$ ).
Although the vertical distribution of carideans varied over the sampling period, their abundance was most often greatest around the fluorescence maximum, generally below the thermocline (Fig. 3f, Table 1). The variation in their abundance was explained by the combination of temperature and fluorescence (Fig. 3f, Table 1). Current velocities ( $w$, $V$ and $u$ ) did not explain any of the variation in caridean abundance (Table 1, Supplement 3). The highest abundance of carideans was found primarily at $18 \mathrm{~m}$; however, at night, their vertical distribution was slightly shallower (Fig. 4, Table 2).

The abundance of brachyurans was greatest above or near the thermocline, but was variable over time (Fig. $3 g$ ). Only $6 \%$ of the variation in their abundance was explained by the thermal structure and none by fluorescence, $w_{1} v$, or $u$ (Table 1, Supplement 3). They exhibited diel vertical migration within the upper mixed layer, and their concentration was greatest above the thermocline at night; they were more evenly distributed throughout the water column during the day (Fig. 4, Table 2).

\section{Estimates of larval transport}

We used progressive vector diagrams to estimate larval transport from our sampling site over a $24 \mathrm{~h}$ period, starting at 10:00, 16:00 and 22:00 h during the full and quarter moon. Estimated larval transport varied among depths $(3,6,9,12,18$ and $23 \mathrm{~m})$ and start times $(10: 00,16: 00$ and 22:00 h), and between sampling periods (full moon and quarter moon) (Fig. 5). Larval transport was in a similar direction in the mixed layer and around the thermocline, but differed in magnitude. In contrast, larval transport below the thermocline at 18 and $23 \mathrm{~m}$ was often in opposite directions (Fig. 5). For example, transport at 18 and

Table 1. Significant relationships (multiple [backwards stepwise] linear regression) that explained most of the variance in larval abundance patterns $(\log [x+2]$ transformed) of different taxonomic groups with different physical and biological variables. Adj. $\mathrm{R}^{2}=$ adjusted $\mathrm{R}^{2}, T=$ temperature (negatively correlated to salinity, density and depth, excluded from analyses), $F l=$ fluorescence, $w=$ vertical velocity, $v=$ north-south velocity, $u=$ east-west velocity

\begin{tabular}{|lcccccc|}
\hline $\begin{array}{l}\text { Taxon } \\
\text { of larvae }\end{array}$ & $\begin{array}{l}\text { Relationship with } \\
\text { larval abundance }\end{array}$ & Adj. $\mathrm{R}^{2}$ & $F$ & df & p & $\begin{array}{c}\text { Part correlation } \\
\text { coefficient }\end{array}$ \\
\hline Gastropods & $0.250-0.062 T$ & 0.142 & 27.75 & 1,161 & $\mathbf{< 0 . 0 0 1}$ & $T:-0.383$ \\
Bivalves & $0.260-0.097 T$ & 0.366 & 94.64 & 1,161 & $<\mathbf{0 . 0 0 1}$ & $T:-0.608$ \\
Polychaetes & $0.275-0.090 T$ & 0.414 & 115.5 & 1,161 & $\mathbf{< . 0 0 1}$ & $T:-0.646$ \\
Bryozoans & $0.267+0.139 F$ & 0.471 & 90.03 & 1,99 & $<\mathbf{0 . 0 0 1}$ & $F l: 0.690$ \\
Asteroids & $0.229+0.165 T+0.048 \mathrm{~V}$ & 0.334 & 35.16 & 2,134 & $\mathbf{< . 0 0 1}$ & $T: 0.519, \mathrm{~V}: 0.265$ \\
Carideans & $0.281+0.075 F l-0.059 T$ & 0.289 & 21.30 & 2,98 & $<\mathbf{0 . 0 0 1}$ & $F 1: 0.459, T:-0.358$ \\
Brachyurans & $0.269+0.042 T$ & 0.060 & 11.37 & 1,161 & $\mathbf{0 . 0 0 1}$ & $T: 0.257$ \\
\hline
\end{tabular}


Full moon: 6-7 August 2009

a) Gastropods

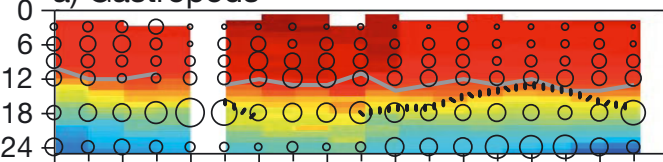

b) Bivalves

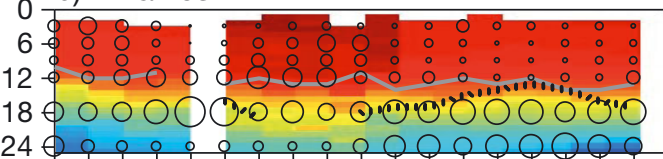

c) Polychaetes

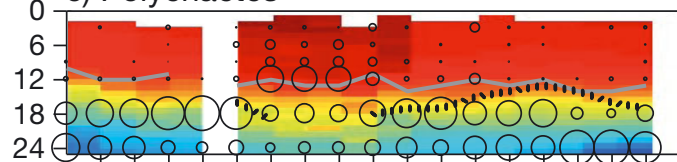

0 d) Bryozoans

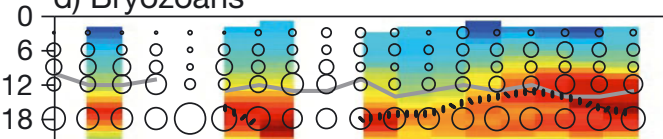

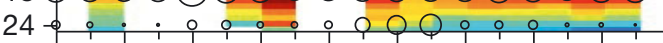

e) Asteroids

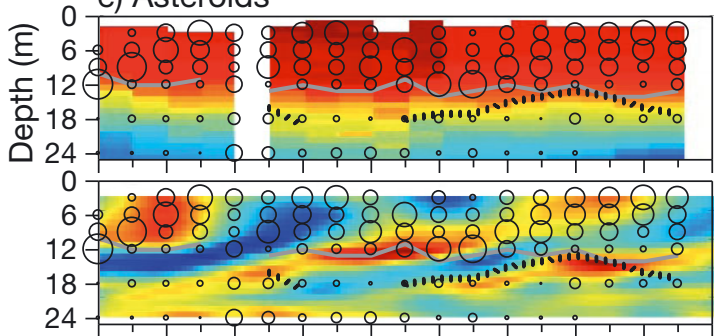

f) Carideans

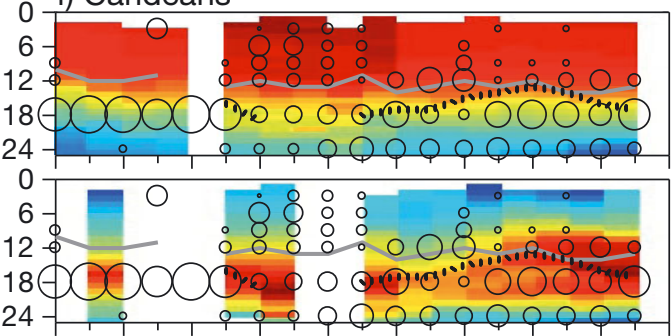

g) Brachyurans

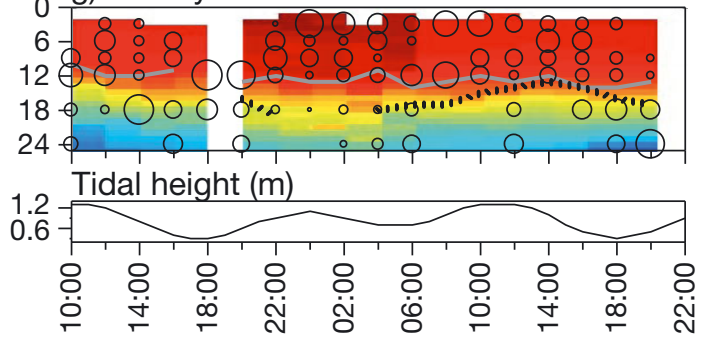

Quarter moon: 12-13 August 2009
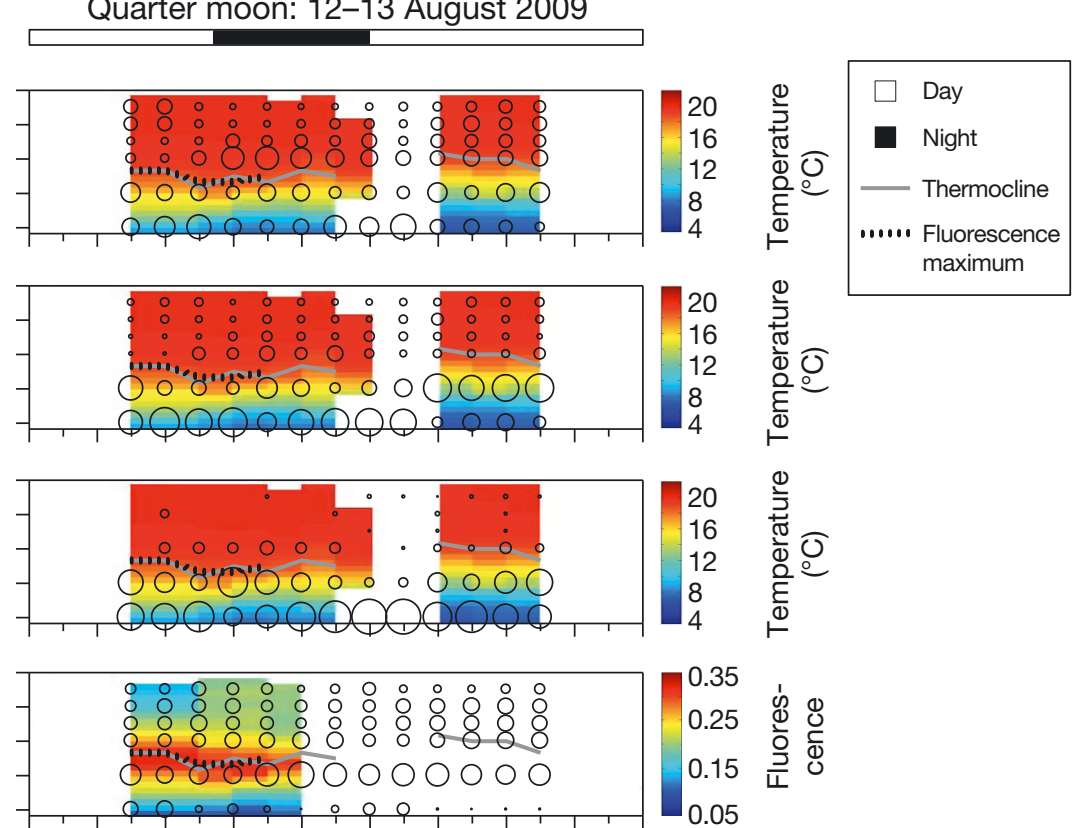

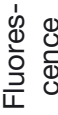

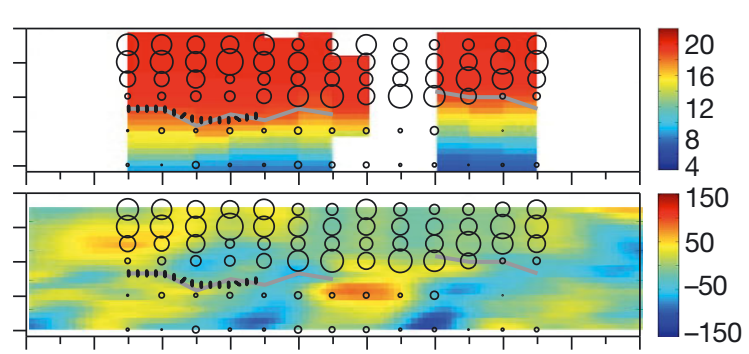

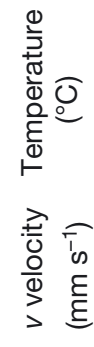

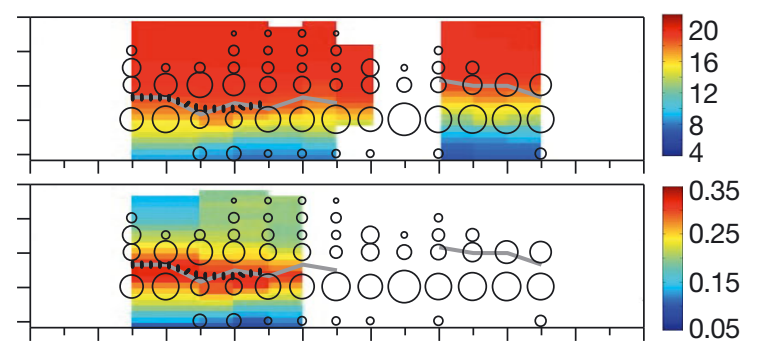

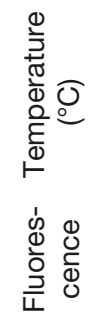

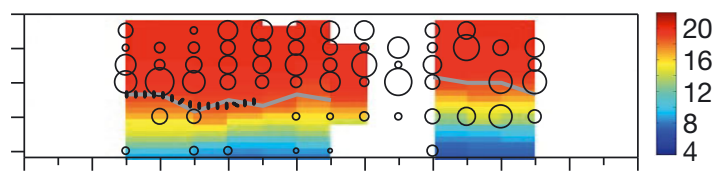

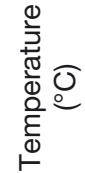

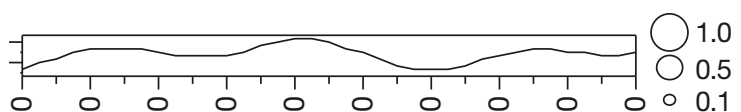

든 은

ㅁํㄴ

Time (hh:mm)

Fig. 3. Vertical distribution of 7 larval taxonomic groups: (a) gastropods, (b) bivalves, (c) polychaetes, (d) bryozoans, (e) asteroids, (f) carideans and (g) brachyurans, over a 36 and $26 \mathrm{~h}$ period, during a spring (full moon: 6-7 August 2009) and neap (quarter moon: 12-13 August 2009) tide, respectively. The proportional abundance was calculated at each depth interval (i.e. $3,6,9,12,18$ and $24 \mathrm{~m}$ ) for each sampling time $j$ using $P_{i j}=n_{i j} / N_{j}$ where $P_{i j}=$ proportional abundance at depth interval $i$ at time $j, n_{i j}=$ number of larvae collected at depth $i$ at time $j$, and $N_{j}=$ total number of larvae sampled at time $j$. The proportional abundance was used to standardize larval concentrations for each taxon within and among sampling periods. Circle size indicates the proportional abundance of larvae for a particular sampling time Colored contours: temperature, fluorescence or $v$ (northsouth velocity) depending on taxonomic group (Only the significant factors are shown for each taxonomic group, as determined by multiple [backwards stepwise] linear regressions) 

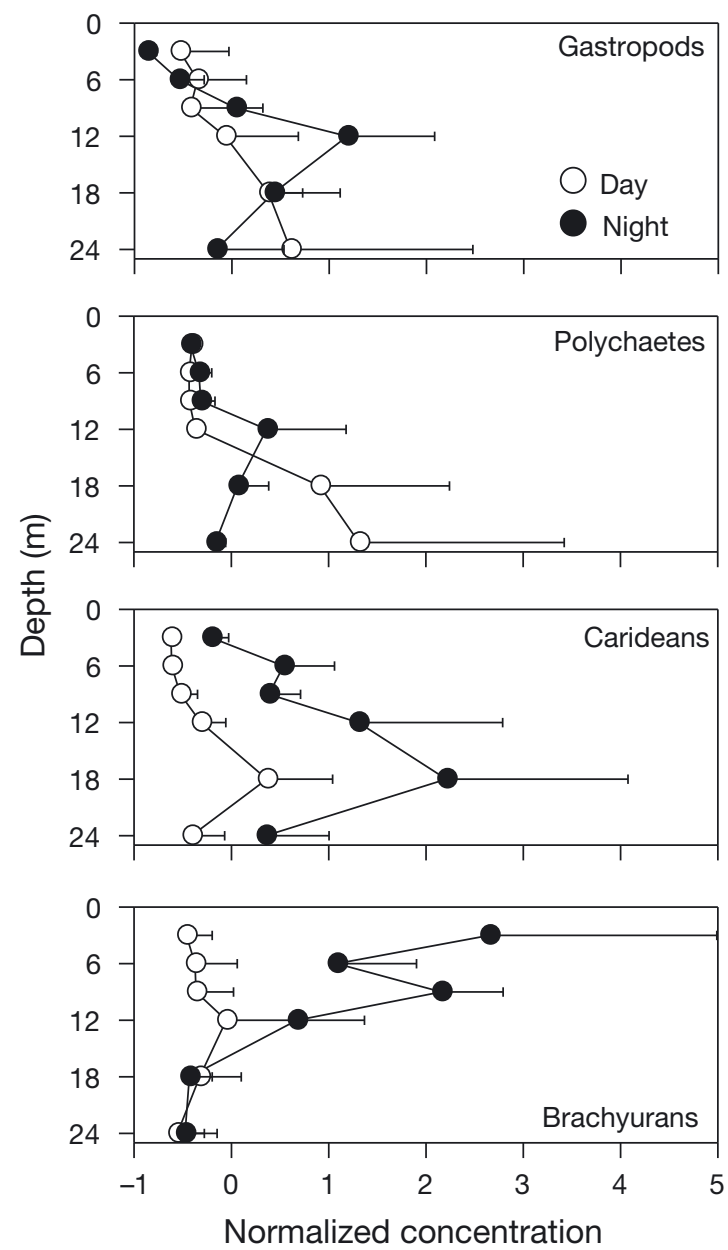

Fig. 4. Vertical distribution of normalized abundance for 4 larval taxonomic groups (gastropods, polychaetes, brachyurans and carideans) which exhibited a significant interaction between depth and diel period (mean \pm SD, $n=3-18$ ) in St. George's Bay, Nova Scotia, Canada

$23 \mathrm{~m}$ during the quarter moon was westward and southward, respectively. The direction and distance of larval transport over the $24 \mathrm{~h}$ period was more similar between the 10:00 and 16:00 h start times than the 22:00 h start time. Transport direction shifted, either clockwise or counter-clockwise, depending on depth, as start time changed from 10:00 to $16: 00$ to 22:00 h (Fig. 5, Table 4). Overall, larval excursions were greater during the full moon than the quarter moon, and larval transport was greatest at $12 \mathrm{~m}$ during the full moon and at $23 \mathrm{~m}$ during the quarter moon (Fig. 5, Table 4). Diel migration either increased or decreased transport (Fig. 5, Table 4). For example, particles migrating from $23 \mathrm{~m}$ during the day to $12 \mathrm{~m}$ at night were transported further than those remaining at $23 \mathrm{~m}$ during the full moon, and nearer during the quarter moon (Fig. 5, Table 4). In contrast, migration from $18 \mathrm{~m}$ during the day to $3 \mathrm{~m}$ at night generally increased transport distance relative to those at $18 \mathrm{~m}$, but altered direction (Fig. 5, Table 4).

\section{DISCUSSION}

\section{Spatial and temporal patterns in vertical distribution}

We have demonstrated that larval vertical distribution varies among taxonomic groups. Observed patterns fall under 1 of 4 categories: (1) larvae found exclusively in the mixed layer, (2) larvae found predominantly below the thermocline, halocline and pycnocline, (3) larvae associated predominantly with the fluorescence maximum (and found below the pycnocline), and (4) larvae with dielly varying distributions. As a consequence, larvae in each of these categories experience different flow regimes, particularly where current intensity or direction are depth-dependent, which may alter their transport.

Late-staged larval asteroids were the only taxonomic group to be found almost exclusively in the mixed layer. In general, echinoderm larvae (e.g. asteroid, Odontaster validus and Asterias rubens) aggregate in the surface layer in field (Pearse \& Bosch 1986, Greenwood et al. 2001) and laboratory studies (Sameoto \& Metaxas 2008 a, b, Daigle \& Metaxas 2011). Even though larval asteroids are weak swimmers (e.g. A. rubens: $0.03 \mathrm{~cm} \mathrm{~s}^{-1}$ ) (Chia et al. 1984), they may be able to actively regulate their vertical position within the water column. For example, earlystage larval asteroids (A. rubens) are known to swim towards the water surface, regardless of the thermal structure of the water column (Daigle \& Metaxas 2011). However, larval asteroid vertical movement may be inhibited in response to lethal or extreme temperatures $\left(>24^{\circ} \mathrm{C}\right.$ ) (Daigle \& Metaxas 2011, C. Civelek unpubl. data) and salinities $(<24)$ (Sameoto \& Metaxas, 2008a, b). Once within the mixed layer, asteroid larvae may actively maintain their position. A consequence of remaining within the mixed layer in our study may be a shortened planktonic duration, as a result of the warm temperatures there $\left(\sim 20^{\circ} \mathrm{C}\right)$. However, many asteroid larvae are planktotrophic, and the mixed layer in St. George's Bay may be food limited (Strathmann 1987). Asteroid transport is most likely the result of advection in the mixed layer, potentially transporting larvae towards the western shore of St. George's Bay during the full moon, and promoting retention during the quarter moon. 
Table 2. ANOVA examining the effects of diel period (day and night) and depth $(3,6,9,12,18$ and $24 \mathrm{~m}$, see numbers in multiple comparisons [Tukey's tests]) on the normalized abundance of 7 taxonomic groups $(\alpha=0.01$, significant $p$-valves indicated in bold). Only significant differences are shown. Depths separated by commas are ordered sequentially (3 to $24 \mathrm{~m}$ ), not according to relative larval abundance at each depth. ns $=$ no significant difference

\begin{tabular}{|c|c|c|c|c|}
\hline $\begin{array}{l}\text { Taxon and } \\
\text { source }\end{array}$ & $\mathrm{df}$ & $F$ & $\mathrm{p}$ & $\begin{array}{l}\text { Multiple comparisons } \\
\text { Low } \longrightarrow \text { High abundance }\end{array}$ \\
\hline \multicolumn{5}{|l|}{ Gastropods } \\
\hline Diel period $(D)$ & 1 & 0.247 & 0.620 & Day: $3,6,9<24 ; 3<18$ \\
\hline Depth $(Z)$ & 5 & 6.093 & $<0.001$ & Night: $3,6<12$ \\
\hline$D \times Z$ & 5 & 3.012 & 0.013 & \\
\hline \multicolumn{5}{|l|}{ Bivalves } \\
\hline$D$ & 1 & 5.268 & 0.023 & Diel Period: Day < Night \\
\hline$Z$ & 5 & 13.22 & $<0.001$ & Depth: $3,6,9,12<18,24$ \\
\hline$D \times Z$ & 5 & 1.491 & 0.197 & \\
\hline \multicolumn{5}{|l|}{ Polychaetes } \\
\hline$D$ & 1 & 1.725 & 0.191 & Day: $3,6,9,12<18,24$ \\
\hline$Z$ & 5 & 4.395 & $<0.001$ & Night: NS \\
\hline$D \times Z$ & 5 & 3.374 & 0.007 & \\
\hline \multicolumn{5}{|l|}{ Bryozoans } \\
\hline$D$ & 1 & 0.159 & 0.69 & Depth: $3,6,9,12,24<18 ; 3,6$, \\
\hline$Z$ & 5 & 47.76 & $<0.001$ & $24<12 ; 3,24<6,9$ \\
\hline$D \times Z$ & 5 & 1.286 & 0.274 & \\
\hline \multicolumn{5}{|l|}{ Asteroids } \\
\hline$D$ & 1 & 8.626 & 0.004 & Diel Period: Night < Day \\
\hline$Z$ & 5 & 8.881 & $<0.001$ & Depth: $18,24<3,6,9,12$ \\
\hline$D \times Z$ & 5 & 1.254 & 0.288 & \\
\hline \multicolumn{5}{|l|}{ Carideans } \\
\hline$D$ & 1 & 100.9 & $<0.001$ & Day: $3,6,9,24<18$ \\
\hline$Z$ & 5 & 19.77 & $<0.001$ & Night: $3,6,9,24<18 ; 3<12$ \\
\hline$D \times Z$ & 5 & 3.909 & 0.002 & \\
\hline \multicolumn{5}{|l|}{ Brachyurans } \\
\hline$D$ & 1 & 108.1 & $<0.001$ & Day: NS \\
\hline$Z$ & 5 & 18.07 & $<0.001$ & Night: $6,12,18,24<3,9 ; 18$ \\
\hline$D \times Z$ & 5 & 18.38 & $<0.001$ & $24<6,12$ \\
\hline Error & 132 & & & \\
\hline
\end{tabular}

a mechanism to avoid stressful environmental conditions. Often, larval bivalves, gastropods and polychaetes are found in cooler and more saline waters, deeper in the water column (Martin et al. 1997, Garland et al. 2002, Lloyd et al. 2012) or mostly around the sediment-water interface (Baker \& Mann 2003). In St. George's Bay, larval bivalves, gastropods and polychaetes may maintain their position below the thermocline where fluorescence concentrations are high to optimize feeding and minimize the risk of predation; however, cooler water temperatures likely increase planktonic larval durations and transport potential. In St. George's Bay, below the thermocline, currents generally flow in the opposite direction between 18 and $23 \mathrm{~m}$. Consequently, bivalve larvae may be recirculated around our sampling site or transported towards the mouth of the bay during the full moon. In contrast, during the quarter moon, transport was shoreward to either the west or the east. Gastropods and polychaetes would experience similar transport to that of bivalves; however, their horizontal transport pattern would also be affected by diel vertical migration (see the last 2 paragraphs of this section).

Larval bryozoans and carideans differ greatly in life histories, morpholo-

Larval gastropods, bivalves and polychaetes were found predominantly below the thermocline, halocline and pycnocline. The presence of a thermocline or a halocline often restricts the vertical distribution of larval bivalves, e.g. Placopecten magellanius, Mytilus edulis and Argopecten irradians (Tremblay \& Sinclair 1990b, Gallager et al. 1996, Sameoto \& Metaxas 2008b, Daigle \& Metaxas 2011). In laboratory studies, rapid changes in temperature and salinity appear to elicit a behavioural response in bivalves, potentially altering their swimming direction (Gallager et al. 1996, Sameoto \& Metaxas 2008b, Daigle \& Metaxas 2011). The magnitude of the salinity gradient $(\Delta \mathrm{S}>8)$ needed to elicit a response in larval bivalves is nowhere near the magnitude observed in our study (Mann et al. 1991, Sameoto \& Metaxas 2008b). This response may have evolved as gies and swimming abilities, yet both were found to aggregate around the fluorescence maximum, below the pycnocline. While bryozoans feed exclusively on phytoplankton (Strathmann 1987), only caridean stages I and II do (Ouellet \& Allard 2006). In the field and laboratory, the vertical distribution of planktotrophic larvae is often related to the presence of food patches (Raby et al. 1994, Metaxas \& Young 1998, Sameoto \& Metaxas 2008b). Both bryozoan and caridean larvae have the chemosensory ability to detect food (Kingsford et al. 2002), and laboratory observations have shown directed movement towards food supply for the decapod, Nihonotrypaea harmandi (Tamaki et al. 2010). Once within the food patch (i.e. food is detected), larvae may modify their swimming to remain within the patch (Metaxas \& Young 1998), optimizing their feeding potential 
Table 3. Results of ANOVA examining the effects of tidal (ebb, flood, high and low) state and depth $(3,6,9,12,18$ and $24 \mathrm{~m})$ on the normalized abundance of 7 taxonomic groups ( $\mathrm{p}<0.01$, indicated in bold, see numbers in multiple comparisons [Tukey's tests]). Only significant differences are shown. Depths separated by commas are ordered sequentially (3 to $24 \mathrm{~m}$ ), not according to relative larval abundance at each depth

\begin{tabular}{|c|c|c|c|c|}
\hline $\begin{array}{l}\text { Taxon and } \\
\text { source }\end{array}$ & df & $F$ & $\mathrm{p}$ & $\begin{array}{l}\text { Multiple comparisons } \\
\text { Low } \longrightarrow \text { High abundance }\end{array}$ \\
\hline \multicolumn{5}{|l|}{ Gastropods } \\
\hline Tidal State (Ti) & 3 & 0.691 & 0.559 & \multirow[t]{3}{*}{ Depth: $3,6,9<18,24 ; 3,6<12$} \\
\hline Depth $(Z)$ & 5 & 9.627 & $<0.001$ & \\
\hline$T i \times Z$ & 15 & 1.514 & 0.106 & \\
\hline \multicolumn{5}{|l|}{ Bivalves } \\
\hline $\mathrm{Ti}$ & 3 & 1.052 & 0.371 & \multirow[t]{3}{*}{ Depth: $3,6,9,12<18,24$} \\
\hline$Z$ & 5 & 23.672 & $<0.001$ & \\
\hline$T i \times Z$ & 15 & 1.411 & 0.148 & \\
\hline \multicolumn{5}{|l|}{ Polychaetes } \\
\hline $\mathrm{Ti}$ & 3 & 1.199 & 0.312 & \multirow[t]{3}{*}{ Depth: $3,6,9,12<18,24$} \\
\hline$Z$ & 5 & 12.506 & $<0.001$ & \\
\hline$T i \times Z$ & 15 & 0.829 & 0.644 & \\
\hline \multicolumn{5}{|l|}{ Bryozoans } \\
\hline $\mathrm{Ti}^{\mathrm{T}}$ & 3 & 4.427 & 0.005 & \multirow{3}{*}{$\begin{array}{l}\text { Tidal State: Low < Flood, High } \\
\text { Depth: } 3,6,9,12,24<18 ; 3,6 \text {, } \\
24<9,12 ; 3<6\end{array}$} \\
\hline$Z$ & 5 & 67.278 & $<0.001$ & \\
\hline$T i \times Z$ & 15 & 0.511 & 0.932 & \\
\hline \multicolumn{5}{|l|}{ Asteroids } \\
\hline $\mathrm{Ti}$ & 3 & 4.68 & 0.004 & \multirow{3}{*}{$\begin{array}{l}\text { Tidal State: Flood }<\text { Ebb, High } \\
\text { Depth: } 18,24<3,6,9,12\end{array}$} \\
\hline$Z$ & 5 & 16.924 & $<0.001$ & \\
\hline$T i \times Z$ & 15 & 0.749 & 0.731 & \\
\hline \multicolumn{5}{|l|}{ Carideans } \\
\hline$T i$ & 3 & 0.526 & 0.665 & \multirow{3}{*}{$\begin{array}{l}\text { Depth: } 3,6,9,12,24<18 \\
3<12\end{array}$} \\
\hline$Z$ & 5 & 11.385 & $<0.001$ & \\
\hline$T i \times Z$ & 15 & 0.537 & 0.917 & \\
\hline \multicolumn{5}{|l|}{ Brachyurans } \\
\hline$T i$ & 3 & 0.783 & 0.505 & \\
\hline$Z$ & 5 & 2.817 & 0.018 & \\
\hline$T i \times Z$ & 15 & 0.593 & 0.877 & \\
\hline Error & 162 & & & \\
\hline
\end{tabular}

Diel vertical migration was exhibited by larval gastropods, polychaetes, carideans and brachyurans, suggesting a potential adaptive significance to their migration. Light is inferred as the cue that drives vertical migration for all these taxonomic groups (Petipa 1955 as cited in Mileikovsky 1973, Daro 1974, Forward 1985), often as a result of negative phototaxis. This response may have evolved as a mechanism by which larvae may avoid predation (particularly visual predators such as fish) (as suggested by Cronin \& Forward 1986, Garland et al. 2002, dos Santos et al. 2008) or optimize feeding, increasing survival (Hays 2003). In St. George's Bay, the fishes Gasterosteus aculeatus and Merluccius bilinearis are known to feed on larval gastropods, bivalves and crustaceans (Short et al. 2012). In our study, the mechanism driving the migratory behaviour is uncertain. Gastropods and polychaetes are also known planktotrophic herbivores. These larvae may either feed below the pycnocline during the day, and migrate into the mixed layer at night, or may migrate from just above the seafloor to the fluorescence maximum layer (13-18 $\mathrm{m}$ depth) at night to feed.

The magnitude of diel vertical migration varied among taxonomic groups, potentially leading to differ(Young 1995). In St. George's Bay, for bryozoans and carideans to remain within the layer of fluorescence maximum would require a combination of swimming and buoyancy. Bryozoans are small, and are weak swimmers compared to carideans (Chia et al. 1984), but are probably less dense. Increased feeding opportunity can shorten planktonic larval duration, increasing survival and potentially decreasing dispersal distance (Pechenik 1987). Within the layer of the fluorescence maximum, current velocities may promote recirculation of bryozoan larvae during the full moon, and advect them towards the westward shore of St. George's Bay during the quarter moon. Carideans would experience similar transport to bryozoans; however, their horizontal transport pattern would also be affected by diel vertical migration (see the last 2 paragraphs of this section). ences in transport distance and direction. Gastropods and polychaetes migrated a distance of $\sim 6-12 \mathrm{~m}$, from just above the seafloor to just above the thermocline at night, while carideans and brachyurans migrated a distance of $>12 \mathrm{~m}$, from below the thermocline to the surface. This difference in magnitude may result from differences in size, ontogenetic stage, or swimming ability. Due to their small size and weak swimming abilities, larval gastropods and polychaetes may be unable to migrate over the entire water column. Decapod larvae are known to vertically migrate the greatest distances (20-50 m) (dos Santos et al. 2008), whereas gastropod vertical migrations tend to be short (Garland et al. 2002, Lloyd et al. 2012). For some gastropods and polychaetes, the speed of active movement is adequate to migrate through most of the water column in $1.4-7 \mathrm{~h}$ 


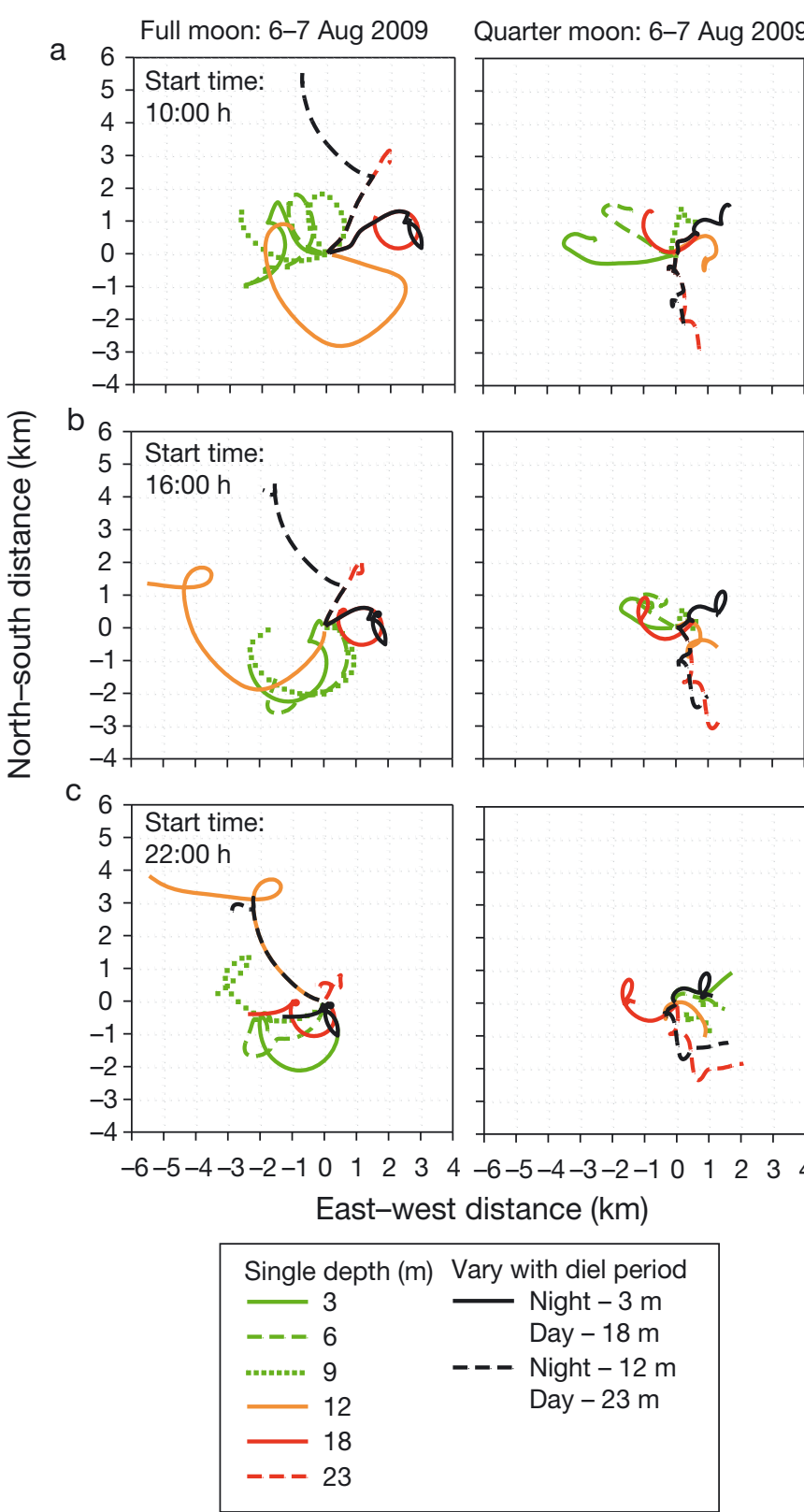

Fig. 5. Progressive vector diagram estimating larval transport from our sampling site $(45.78 \mathrm{~N}, 61.80 \mathrm{~W}$; depth $=25 \mathrm{~m})$ in St. George's Bay, Nova Scotia, Canada, over a 24 h sampling period, during a spring (full moon: 6-7 August 2009) and neap (quarter moon: 12-13 August 2009) tide, respectively. Larval transport estimated from current velocities with start times at (a) 10:00 h, (b) 16:00 h and (c) 22:00 h on 6 and 12 August 2009. Green line: mixed layer, yellow line: depths around thermocline, red line: depths below the thermocline and black line: depth-varying particles

(i.e. $25 \mathrm{~m}$ at $0.1-0.5 \mathrm{~cm} \mathrm{~s}^{-1}$ ) (Mileikovsky 1973). It is unknown, however, whether they swim the entire depth of the water column or their depth-range is constrained by water column structure (i.e. ther- mocline, halocline, pycnocline etc.). Consequently, these taxonomic groups experience different flow regimes, and may have very different transport patterns. For gastropods and polychaetes, diel vertical migration from near the seafloor to just above the thermocline at night would have promoted transport towards the mouth of St. George's Bay during the full moon and the southern shore during the quarter moon. For brachyurans and carideans, vertical migration from below the thermocline to the surface at night would have promoted retention in the vicinity of the sampling site during the full moon and transport towards the eastern shore during the quarter moon.

\section{Linking behavioural responses to field vertical distributions}

Laboratory studies are often used to provide first order estimates of larval behaviour likely to be observed in the field, and field larval distributions measured at high temporal frequencies can be used to test the validity of these estimates. We observed vertical distributions of bivalve and asteroid larvae in the field that are similar to those reported in laboratory studies (Gallager et al. 1996, Sameoto \& Metaxas 2008b, Daigle \& Metaxas 2011). For example, larval asteroids swim upwards and remain in the upper layers of the water column (Sameoto \& Metaxas 2008b, Daigle \& Metaxas 2011), and remain below a discontinuity when temperatures above the thermocline exceed $24^{\circ} \mathrm{C}$ (Daigle \& Metaxas 2011) or the halocline is strong $(\Delta \mathrm{S}>8)$ (Sameoto \& Metaxas 2008b). Our observation that planktotrophic herbivores aggregated around or within the fluorescence maximum in the field can be explained by behaviours observed in the laboratory (Metaxas \& Young 1998, Burdett-Coutts \& Metaxas 2004, Sameoto \& Metaxas 2008b). For example, in the laboratory, bivalves migrate towards food when it is present (Sameoto \& Metaxas 2008b). Changes in the vertical distribution of bivalves with diel period are observed both in the field and laboratory (Tremblay \& Sinclair 1990a, Gallager et al. 1996), and the range of migration observed in both settings appears to coincide with the discontinuity layer. For example, the bivalve Placopecten magellanicus was found in high abundance at the surface at night, and at the thermocline during the day, regardless of the vertical position of food (Tremblay \& Sinclair 1990b, Gallager et al. 1996). Similar to these studies, we observed migration in gastropods and polychaetes from near the seafloor to 
Table 4. Larval transport of all taxonomic groups over short temporal scales, based on their vertical distribution at our sampling site in St. George's Bay, Nova Scotia, Canada. Estimates of larval transport were calculated from progressive vector plots (Fig. 5) for a $24 \mathrm{~h}$ period, using 3 start times (10:00, 16:00 and 22:00 h) and over both sampling periods (see Methods for details). For larvae in the mixed layer $(3,6$ and $9 \mathrm{~m}$ ), below the thermocline (halocline and pycnocline; 18 and $23 \mathrm{~m}$ ) or associated with the fluorescence maximum layer $(18 \mathrm{~m})$, transport was calculated at a single depth. For larvae that varied with diel period, transport was calculated using a combination of 2 depths: either 3 and $18 \mathrm{~m}$ (carideans, brachyurans) and 12 and $24 \mathrm{~m}$ (gastropods, bivalves). $\mathrm{N}=$ north, $\mathrm{S}=$ south, $\mathrm{W}=$ west, $\mathrm{E}=$ east

\begin{tabular}{|c|c|c|c|c|c|c|c|}
\hline \multirow[t]{2}{*}{ Category } & \multirow{2}{*}{$\begin{array}{c}\text { Taxonomic } \\
\text { group }\end{array}$} & \multicolumn{4}{|c|}{ Larval transport $(\mathrm{km})$} & \multirow[b]{2}{*}{$\begin{array}{c}\text { - Quarter moon } \\
16: 00 \mathrm{~h}\end{array}$} & \multirow[b]{2}{*}{$22: 00 \mathrm{~h}$} \\
\hline & & $10: 00 \mathrm{~h}$ & $\begin{array}{l}\text { Full moon } \\
16: 00 \mathrm{~h}\end{array}$ & $22: 00 \mathrm{~h}$ & $\overline{10: 00 \mathrm{~h}}$ & & \\
\hline In the mixed layer & Asteroids & $\begin{array}{l}2.5 \mathrm{SW} \\
2.9 \mathrm{SW} \\
3.0 \mathrm{NW}\end{array}$ & $\begin{array}{c}2.6 \mathrm{SW} \\
2.2 \mathrm{SW} \\
1.6 \mathrm{~W}\end{array}$ & $\begin{array}{l}1.8 \mathrm{~W} \\
2.1 \mathrm{~W} \\
3.4 \mathrm{~W}\end{array}$ & $\begin{array}{c}2.5 \mathrm{~W} \\
1.9 \mathrm{NW} \\
1.1 \mathrm{NE}\end{array}$ & $\begin{array}{c}1.0 \mathrm{NW} \\
0.8 \mathrm{NW} \\
0.5 \mathrm{E}\end{array}$ & $\begin{array}{c}2.0 \mathrm{NE} \\
1.5 \mathrm{E} \\
1.4 \mathrm{SE}\end{array}$ \\
\hline Below thermocline & Bivalves & $\begin{array}{l}\text { 1.9 NE } \\
\text { 3.4 NE }\end{array}$ & $\begin{array}{l}0.8 \mathrm{NE} \\
2.0 \mathrm{NE}\end{array}$ & $\begin{array}{l}2.4 \mathrm{~W} \\
0.6 \mathrm{NW}\end{array}$ & $\begin{array}{c}1.5 \mathrm{NW} \\
3.0 \mathrm{~S}\end{array}$ & $\begin{array}{l}1.1 \mathrm{~W} \\
3.1 \mathrm{~S}\end{array}$ & $\begin{array}{l}1.3 \mathrm{~W} \\
2.8 \mathrm{SE}\end{array}$ \\
\hline $\begin{array}{l}\text { Associated with the } \\
\text { fluorescence maximum }\end{array}$ & $\begin{array}{l}\text { Bryozoans } \\
\text { Carideans }\end{array}$ & $1.9 \mathrm{NE}$ & $0.8 \mathrm{NE}$ & $2.4 \mathrm{~W}$ & $1.5 \mathrm{NW}$ & $1.1 \mathrm{~W}$ & $1.3 \mathrm{~W}$ \\
\hline Vary with diel period & $\begin{array}{c}\text { Gastropods } \\
\text { Polychaetes } \\
\text { Carideans }\end{array}$ & $2.8 \mathrm{~W}$ & $1.7 \mathrm{~W}$ & $1.4 \mathrm{~W}$ & $2.2 \mathrm{NE}$ & $1.4 \mathrm{NE}$ & $1.1 \mathrm{E}$ \\
\hline & Brachyurans & $5.2 \mathrm{~N}$ & $4.6 \mathrm{~N}$ & $4.2 \mathrm{NW}$ & $2.3 \mathrm{~S}$ & $2.3 \mathrm{~S}$ & $2.0 \mathrm{SE}$ \\
\hline
\end{tabular}

the thermocline at night, but not in bivalves. Therefore, some simple behaviours of bivalves and asteroids studied in the laboratory can be used to explain general patterns observed in the field, and to derive biological parameters. There have been no studies examining responses of gastropods, polychaetes, bryozoans and carideans to physical (temperature, salinity, current velocity, light) or biological (food) cues, except one study examining the response of carideans to thermal gradients (Ouellet \& Allard 2006).

In contrast to bivalves and asteroids, few generalizations can be made about the behaviour of brachyurans. Most brachyurans respond to light and pressure cues in field and laboratory, which generally concurs with our observations. Both in the laboratory and in the field behavioural responses vary among species and larval stages (zoea and megalopae) (Brookins \& Epifanio 1985, Cronin \& Forward 1986, Forward \& Wellins 1989, Garrison 1999, DiBacco et al. 2001). For example, megalopae were found near the surface at flooding tide, while zoea were at the surface during ebbing tide (Brookins \& Epifanio 1985). Under the same tidal state and flow regime, zoea of Pachygrapsus crassipes also exhibited vertical migration, while those of Lophopanopeus spp. did not (DiBacco et al. 2001). The complexity of responses by brachyurans requires the collection of species-, stage- and system-specific information that can be used to parameterize their behaviour.

\section{CONCLUSIONS}

We identified 4 different patterns of vertical distribution for the larvae in St. George's Bay, (1) within the mixed layer, (2) below the thermocline, halocline and pycnocline, (3) associated with the fluorescence maximum and (4) migrating from below the thermocline, halocline and pycnocline to the mixed layer. We have suggested that transport can vary across the 4 different patterns of vertical distribution. These results indicate the importance of vertical structure and diel vertical migration in larval retention and transport. Our results are particularly relevant for application in biophysical models, in that they demonstrate how variability in dispersal depends upon observed current structure in each of the identified layers, which is often poorly represented in physical models (Stow et al. 2009). Further, our study shows that 4 different groups of larvae of commonly observed coastal marine organisms exhibit 4 different models for vertical structure. We suggest that these results could be explored further in biophysical numerical simulation models (deYoung et al. 2010) in other regions where similar species are found. For most taxonomic groups, simple field measurements of water-column structure (e.g. temperature and fluorescence profile) in the field, linked to behavioural responses in the laboratory, can be used to improve the parameterization of biological components of biophysical models. More controlled laboratory experiments examining behavioural responses of a variety 
of larvae to different physical (e.g. temperature, salinity, discontinuities, pressure, light, etc.) and biological (food, predators and conspecifics) cues, as well as combinations of these cues (e.g. diel period and discontinuities) are needed for comparison with field distributions. It is possible that for each taxonomic group, the behavioural component of the model can be relatively simple. With valid biological parameters, we can ultimately improve the quality of transport estimates generated using biophysical models for different taxonomic groups.

Acknowledgements. We thank R. Daigle, J. Short, S. Henderson, D. Ross, R. Stanley, J. Foley and J. Hrycik for assistance in the field; M. Merrimen, J. Lindley, W. Judge, D. Shillinger, C. Taggart and J. Grant for providing and assisting with equipment; A. Roy and R. Horricks for assistance in the laboratory; T. Ross, K.Colbo and M. Lesperance for assistance with data processing. This study was done within the Canadian Healthy Oceans Network (CHONe). The research was funded by grants from the NSERC Strategic Network CHONe to A.M. and B.deY., and by a National Sciences and Engineering Research Council (NSERC) Discovery Grant to A.M. M.J.L. was supported by fellowships from NSERC, CHONe and the Faculty of Graduate Studies, Dalhousie University. Biogeographical data contained in this study will be submitted to the Oceanographic Biogeographic Information System (OBIS) and may be accessed on-line at www.iobis.org

\section{LITERATURE CITED}

Baker P, Mann R (2003) Later stage bivalve larvae in a wellmixed estuary are not inert particles. Estuaries 26: 837-845

Brookins KG, Epifanio CE (1985) Abundance of brachyuran larvae in a small coastal inlet over six consecutive tidal cycles. Estuaries 8:60-67

Burdett-Coutts V, Metaxas A (2004) The effect of the quality of food patches on larval vertical distribution of the sea urchins Lytechinus variegatus (Lamarck) and Strongylocentrotus droebachiensis (Mueller). J Exp Mar Biol Ecol 308:221-236

Chia FS, Buckland-Nicks J, Young CM (1984) Locomotion of marine invertebrate larvae - a review. Can J Zool 62: 1205-1222

Cronin TW, Forward RB (1986) Vertical migration cycles of crab larvae and their role in larval dispersal. Bull Mar Sci 39:192-201

> Daigle RM, Metaxas A (2011) Vertical distribution of marine invertebrate larvae in response to thermal stratification in the laboratory. J Exp Mar Biol Ecol 409:89-98

$>$ Daro MH (1974) Study of nycthemeral migrations of zooplankton in a shallow marine biotope. Hydrobiologia 44: 149-160

deYoung B, Werner F, Batchelder H, Carlotti F Fiksen, Hofmann EE, Kim S, Yamazaki H, Kishi M (2010) Dynamics of marine ecosystems: integration through models of biological-physical interactions. In: Barange M, Field JG, Harris RH, Hofmann E, Perry RI, Werner F (eds) Marine ecosystems and global change. Oxford University Press, Oxford

> DiBacco C, Sutton D, McConnico L (2001) Vertical migration behavior and horizontal distribution of brachyuran larvae in a low-inflow estuary: implications for bay-ocean exchange. Mar Ecol Prog Ser 217:191-206

dos Santos A, Santos AMP, Conway DVP, Bartilotti C, Lourenco P, Queiroga H (2008) Diel vertical migration of decapod larvae in the Portuguese coastal upwelling ecosystem: implications for offshore transport. Mar Ecol Prog Ser 359:171-183

Forward RB (1985) Behavioral responses of larvae of the crab Rhithropanopeus harrisii (Brachyura, Xanthidae) during diel vertical migration. Mar Biol 90:9-18

> Forward RB, Wellins C (1989) Behavioral responses of a larval crustacean to hydrostatic pressure: Rhithropanopeus harrisii (Brachyura: Xanthidae). Mar Biol 101:159-172

> Gallager S, Manuel J, Manning D, O'Dor R (1996) Ontogenetic changes in the vertical distribution of giant scallop larvae, Placopecten magellanicus, in $9 \mathrm{~m}$ deep mesocosms as a function of light, food, and temperature stratification. Mar Biol 124:679-692

> Garland ED, Zimmer CA, Lentz SJ (2002) Larval distributions in inner-shelf waters: the roles of wind-driven cross-shelf currents and diel vertical migrations. Limnol Oceanogr 47:803-817

- Garrison LP (1999) Vertical migration behavior and larval transport in brachyuran crabs. Mar Ecol Prog Ser 176: 103-113

Gawarkiewicz G, Monismith S, Largier J (2007) Observing larval transport processes affecting population connectivity: progress and challenges. Oceanography (Wash DC) 20:40-53

Gilbert CS, Gentleman WC, Johnson CL, DiBacco C, Pringle JM, Chen C (2010) Modelling dispersal of sea scallop (Placopecten magellanicus) larvae on Georges Bank: the influence of depth-distribution, planktonic duration and spawning seasonality. Prog Oceanogr 87:37-48

Greenwood A, O'Riordan R, Barnes D (2001) Seasonality and vertical zonation of zooplankton in a semi-enclosed sea lough. J Mar Biol Assoc UK 81:213-220

Hays GC (2003) A review of the adaptive significance and ecosystem consequences of zooplankton diel vertical migrations. Hydrobiologia 503:163-170

Huebert K, Cowen R, Sponaugle S (2011) Vertical migrations of reef fish larvae in the Straits of Florida and effects on larval transport. Limnol Oceanogr 56:1653-1666

Kingsford MJ, Leis JM, Shanks AL, Lindeman KC, Morgan SG, Pineda J (2002) Sensory environments, larval abilities and local self-recruitment. Bull Mar Sci 70:309-340

Lesperance M, deYoung B, Foley J (2011) Analysis of physical oceanographic data from St. George's Bay, NS JulyAugust 2009. Physics and Physical Oceanography Data Report 2011-1:1-23. www.physics.mun.ca/ bdeyoung/ 2009report_8feb2011.pdf

Lloyd ML, Metaxas A, deYoung B (2012) Patterns in the vertical distribution of larvae of marine benthic gastropods in a shallow embayment in Nova Scotia, Canada: the role of the physical environment. Mar Ecol Prog Ser 464:135-151

> Mann R, Campos BM, Luckenbach MW (1991) Swimming rate and responses of larvae of three mactrid bivalves to salinity discontinuities. Mar Ecol Prog Ser 68:257-269

> Manuel JL, O'Dor RK (1997) Vertical migration for horizontal transport while avoiding predators: I. A tidal/diel 
model. J Plankton Res 19:1929-1947

Manuel JL, Gallager SM, Pearce CM, Manning DA, O'Dor RK (1996) Veligers from different populations of sea scallop Placopecten magellanicus have different vertical migration patterns. Mar Ecol Prog Ser 142:147-163

Martin D, Claret M, Pinedo S, Sandá R (1997) Vertical and spatial distributions of the near-shore littoral meroplankton off the Bay of Blanes (NW Mediterranean Sea). J Plankton Res 19:2079-2089

> McConnaughey RA, Sulkin SD (1984) Measuring the effects of thermoclines on the vertical migration of larvae of Callinectes sapidus (Brachyura: Portunidae) in the laboratory. Mar Biol 81:139-145

Metaxas A (2001) Behaviour in flow: perspectives on the distribution and dispersion of meroplanktonic larvae in the water column. Can J Fish Aquat Sci 58:86-98

Metaxas A, Burdett-Coutts V (2006) Response of invertebrate larvae to the presence of the ctenophore Bolinopsis infundibulum, a potential predator. J Exp Mar Biol Ecol 334:187-195

Metaxas A, Saunders MI (2009) Quantifying the 'bio-' components in biophysical models of larval transport in marine benthic invertebrates: advances and pitfalls. Biol Bull 216:257-272

> Metaxas A, Young CM (1998) Responses of echinoid larvae to food patches of different algal densities. Mar Biol 130: 433-445

Mileikovsky S. (1973) Speed of active movement of pelagic larvae of marine bottom invertebrates and their ability to regulate their vertical position. Mar Biol 23:11-17

North EW, Schlag Z, Hood RR, Li M, Zhong L, Gross T, Kennedy VS (2008) Vertical swimming behavior influences the dispersal of simulated oyster larvae in a coupled particle-tracking and hydrodynamic model of Chesapeake Bay. Mar Ecol Prog Ser 359:99-115

> Ouellet P, Allard JP (2006) Vertical distribution and behaviour of shrimp Pandalus borealis larval stages in thermally stratified water columns: laboratory experiment and field observations. Fish Oceanogr 15:373-389

Pearse JS, Bosch I (1986) Are the feeding larvae of the commonest Antarctic asteroid really demersal? Bull Mar Sci 39:477-484

Pechenik JA (1987) Environmental influences on larval survival and development. In: Giese AC, Pearse JS, Pearse VB (eds) Reproduction of marine invertebrates, IX, general aspects: seeking unity in diversity. The Boxwood Press, Pacific Grove, CA, p 551-608

$>$ Pennington JT, Emlet RB (1986) Ontogenic and diel vertical migration of a planktonic echinoid larva, Dendraster excentricus (Eschscholtz) - occurrence, causes, and probable consequences. J Exp Mar Biol Ecol 104:69-95

Petipa TS (1955) Observations on zooplankton behavior during the solar eclipse (in Russian). Dokl. Akad. Nauk SSSR. 104:323-325, as cited in Mileikovsky S (1973) Speed of active movement of pelagic larvae of marine bottom invertebrates and their ability to regulate their vertical position. Mar Biol 23:11-17

> Petrie B, Drinkwater K (1978) Circulation in an open bay. J Fish Res Board Can 35:1116-1123

> Poulin E, Palma AT, Leiva G, Narvaez D, Pacheco R, Navar-

Editorial responsibility: Steven Morgan,

Bodega Bay, California, USA rete SA, Castilla JC (2002) Avoiding offshore transport of competent larvae during upwelling events: the case of the gastropod Concholepas concholepas in central Chile. Limnol Oceanogr 47:1248-1255

$>$ Prairie JC, Franks PJS, Jaffe JS (2010) Cryptic peaks: Invisible vertical structure in fluorescent particles revealed using a planar laser imaging fluorometer. Limnol Oceanogr 55:1943-1958

> Raby D, Lagadeuc Y, Dodson JJ, Mingelbier M (1994) Relationship between feeding and vertical distribution of bivalve larvae in stratified and mixed waters. Mar Ecol Prog Ser 103:275-284

Sameoto JA, Metaxas A (2008a) Can salinity-induced mortality explain larval vertical distribution with respect to a halocline? Biol Bull 214:329-338

Sameoto JA, Metaxas A (2008b) Interactive effects of haloclines and food patches on the vertical distribution of 3 species of temperate invertebrate larvae. J Exp Mar Biol Ecol 367:131-141

Shanks AL (1995). Mechanisms of cross-shelf dispersal of larval invertebrates and fish. In: McEdward LR (ed) Ecology of marine invertebrate larvae. CRC Press, Boca Raton, FL, p 323-367

Short J, Metaxas A, Daigle RM (2012) Predation of larval benthic invertebrates in St. Georges Bay, Nova Scotia. J Mar Biol Assoc UK, doi:10.1017/S0025315412000768

> Stow CA, Jollliff J, McGillicuddy DJ Jr, Doney SC and others (2009) Skill assessment for coupled biological/physical models of marine ecosystems. J Mar Syst 76:4-15

Strathmann MF (1987) Reproduction and development of marine invertebrates of the northern Pacific coast. University of Washington Press.

> Tamaki A, Mandal S, Agata Y, Aoki I and others (2010) Complex vertical migration of larvae of the ghost shrimp, Nihonotrypaea harmandi, in inner shelf waters of western Kyushu, Japan. Estuar Coast Shelf Sci 86:125-136

> Tapia FJ, DiBacco C, Jarrett J, Pineda J (2010) Vertical distribution of barnacle larvae at a fixed nearshore station in southern California: stage-specific and diel patterns. Estuar Coast Shelf Sci 86:265-270

Tremblay MJ, Sinclair MM (1990a) Diel vertical migration of sea scallop larvae Placopecten magellanicus in a shallow embayment. Mar Ecol Prog Ser 67:19-25

Tremblay MJ, Sinclair MM (1990b) Sea scallop larvae Placopecten magellanicus on Georges Bank: vertical distribution in relation to water column stratification and food. Mar Ecol Prog Ser 61:1-15

Woods Hole Science Center (2011) SEA-MAT Matlab tools for oceanographic analysis. Available at http:// woodshole.er.usgs.gov/operations/sea-mat/index.html

Young CM (1995) Behavior and locomotion during the dispersal phase of larval life. In: McEdward LR (ed) Ecology of marine invertebrate larvae. CRC Press, Boca Raton, FL, p 249-277

Young CM, Chia FS (1987). Abundance and distribution of pelagic larvae as influenced by predation, behavior, and hydrographic factors. In: Giese AC, Pearse JS, Pearse VB (eds) Reproduction of marine invertebrates, IX, general aspects: seeking unity in diversity. The Boxwood Press, Pacific Grove, CA, p 385-464

Submitted: March 5, 2012; Accepted: August 3, 2012

Proofs received from author(s): November 14, 2012 